\title{
The Use of Social Media and its Effect on University Students' Academic Skills in Iraqi Kurdistan Region
}

\section{Araz Ramazan Ahmad ${ }^{1-2}$}

${ }^{1}$ Department of Administration, College of Humanities, University of Raparin, Rania, Kurdistan Region, Iraq.

${ }^{2}$ Department of International relations \& Diplomacy, Faculty of Administrative Sciences and Economics, Tishk International University, Erbil, Kurdistan Region, Iraq

E-mail: araz.ahmad85@uor.edu.krd

\section{Hakim Othman Hameed}

Public Relations \& Marketing Department, Technical College of Administration, Sulaimani Polytechnic University, Sulaimani, Kurdistan Region, Iraq.

E-mail: hakim.othman@spu.ede.iq

\begin{abstract}
:
In recent decades, the use of social media has encountered a rapid growth. This progress made social media a very popular medium of communication among college students. In fact, these online mediums can be a good method to share the knowledge among students and with their lectures. However, extreme use of social media can affect student's academic performance and skills. Social media platforms have developed significantly in the variety and type of its platforms and the variety of services they have provided to the users. This social media development has had a great impact on human life around the world, particularly the learning process among the students.

The present study examines the effects of social networks on university students' academic skills in Iraqi Kurdistan Region. The sample involved 653 responses from the universities of Raparin and Sulaimani Polytechnic in Kurdistan Region - Iraq. The data of the study has been analyzed using content analysis methods.

According to the study's results there is a statistically significant correlation between Use of social media and academic skills and there is a strong positive correlation between Use of social media and academic skills which is (0.809) and that the significance value is (0.000). Then, the value of R Square for this analysis, is (0.655), this means that $65.5 \%$ of the variance of academic skills must be explored in Use of social media, and the other variables (34.5\%) are due to random error.
\end{abstract}

Keywords: Effects, Social Media, Academic Skills, Iraq, Kurdistan Region. 


\subsection{Introduction}

In recent years, scholars have consistently attempted to investigate the impact of social networks on academic skills of students in institutions. (Mahdiuon, et al., 2019). Also, Information technology has achieved quick changes and has given a rich wellspring of data resources. Moreover, this changes in advanced teaching guidance in all arenas of education in most of the countries around the world (Tang and Austin 2009). Social media is consistently utilized by many individuals, most of whom are youthful and undergraduates (Dahlstrom et al., 2011). This contains different social media platforms. (Dahlstrom 2012; Chugh 2012) The capacity to connect to networks all around the world is a key aspect in the current impact of social media. People from all the countries can easily access the Internet, and practically everyone can utilize it. (Ahmad, A.R. and Hamasaeed, N.H.H.H, 2015)

The utilization of social networks has improved in academic institutions and as instructive means in both parts of education (Al-Rahmi et al., 2014; Chugh and Ruhi, 2018; Adams et al., 2018; Peters et al., 2019). Social media's impact in teaching contains distribution thoughts, the association of university colleges and students, and enabling and obtaining information (AlKhalifa and Garcia 2013). If social networking sites are fitting to the level of intellectual and teaching forms of undergraduates (Yusoff et al., 2017), it can give students speedy admittance to data, give information to other people and put center upon various parts of learning and teaching. Thus, students use social media as a new age of data novelty to understand their instructive objectives. It tends to be contended of getting the components influencing utilization besides job novelty instruction could influence its utilization also its impact (Sánchez et al. 2014) Many techniques of sharing information and news are now available to the public as a result of the advent of social media. (Ahmad, A.R. and Murad, H.R., 2020)

\subsection{Literature review}

Many studies have considered the use of social media and its effect on the academic ability of students in states like the USA, Nigeria, Pakistan, and Saudi Arabia (Al-Khalifa, et al., 2013: Camilia, et al., 2013. Junco, et al., 2011). Social media is Web-based media means that build on the philosophical and then innovative establishments of Web 2.0, then permit the formation and trade user produced satisfied (Kaplan and Haenlein 2010). Social media networks also let operators to make groups, and in addition manage content. in consonance with Kietzmann and colleagues (2011). Social networks contain different roles: individuality, discussion, distribution, attendance, connection, reputes, and collections. Each feature permits the operator to expose a specific surface of social media besides, by advanced features, growing the emotional incentive of social media operators. Social media provides multilevel and multidimensional strategies to users in any organization and civics (Leonardi et al., 2013). Social networks are included of social media platforms (Ivala and Gachago 2012). 
The good effects of online media are numerous, and it is simple to disseminate information and expertise to others. (Saud, M., Ida, R., Abbas, A., Ashfaq, A. and Ahmad, A.R., 2020.), Correspondingly, social media platforms have connected all users through their phones, users nowadays have access to a variety of web-based media channels from all over the world. (Arafat, S.M., Ahmad, A.R., Murad, H.R. and Kakashekh, H.M., 2021). The usage on social media had impacted student's academic performance and skills, also there is a strong positive association among the usage of social networking sites and professional skills (Owusu-Acheaw, and Larson, 2015).

Wiley and Sisson (2006), argue that recent researchers have discovered that more than $90 \%$ percent of school students using social media platforms. Web-based media is and will remain as a significant device in human existence as far correspondence is concerned. Today various structures of training, including distance schooling has been generally disparaged and encouraged to a few degrees through social media networks. Obtaining data both locally and universally from companions, awareness should be given to the users particularly students about the negative and positive side effects of using social media platforms (Kolan, et al., 2018). According to a study which conducted by El-Badawy and Hashem, using social media by students is safe and there is no negative impact from the social networks using on student's scholastic skills because they spend fewer than one hour or more than six hours on social media platforms, or even the normal amount of time which is among one to three and three to six hours a day (El-Badawy, and Hashem, 2015)

\subsection{Educational use of social media}

Currently, in most of the countries, universities and academic institutions rely on online education, and using computers, internet and technology among students and teachers has increased for knowledge aims (Huffman and Huffman 2012). According to a study by (Narayanasamy and Mohamed 2013; Shahbaz and Khan 2017) students use Telegram as it can connect and share information and data in a widespread variety in a short time, which is why it will be helpful for students if they use it for learning process. The usage of electronics is reliant on over

the implementation through the person then is affected via operator inspiration besides purpose (Huffman and Huffman 2012). It's clear that application chats like Telegram can be utilized purposefully in the education process since its availability, sharing of information, learning in groups, modest environments, peer coaching, and less time spent (Alizadeh 2018). 


\subsection{Student engagement via social media}

Courtner (2014) states that for more than 80 years, the theories and context of student participations have been researched. While participating is impactful from the beginning, it is hard to deliver strong meaning to it (Wise et al. 2011). Likewise, Taylor et al. (2011) states that student engagement goes back to 1990-2009. later it explained as "the connection of students applies to pedagogically good actions" (Conner 2011). The youths and university undergraduates (age 18 - 29) are among the highest users of the social media platforms. They use social media platforms for communication, entertaining, and for searching information (Oueder, and Abousaber, 2018) Engagement includes issues such as advancing in college theoretical knowledge, joining with lecturers besides college staff, syllabus events, and through classmates (Junco 2012). Kuh (2009) also highlights session or theoretical participating and outside class participation in connected learning actions. Junco thinks that all forms are significant for the undergraduate's accomplishments. Scholarly commitment besides educational program commitment remains incredible powers of psychology and social improvement also educational accomplishment. Learning and Data Skills for understudies. Indeed, even students who enter college after years are not ready for an advanced degree accomplish better evaluations with expanded academic commitment. (Pascarella and Terenzini 2005; Kuh et al. 2008).

Junco and others (2011) inferred which cooperation of undergraduates also employees in education cycle are further if students are occupied with social media. It is clear that social media could be utilized for example instructive apparatuses to assist students assume a functioning besides community-oriented part. Also, the impact of data innovation as an instructive device indicated that the utilization of technology expanded the degree of commitment and collaboration of students in education environment also in real teaching rooms. It was recommended that some learning location expenses ought to be ascribed dedicated to the advancement of electronics in real class.

Beeland (2002) claims that online information, particularly social media, and different social media platforms, could be operated as pedagogical means with arrangement to growth undergraduate's participation in teaching activities. faculty teachers similarly must use these means to obtain a better consideration of their possible besides, like harmonizing resources aimed at increasing then expanding undergraduate knowledge in learning progression (Ivala and Gachago, 2012). Nevertheless, Junco (2012) stated that social media usage is a substantial bad analyst of student participation. 


\subsection{Academic skills and use of social media for students.}

Social media platforms are electronic apparatuses which utilized aimed at correspondence, collaborative teaching, and innovative articulation then are useful for reinforcing instruction on colleges and advanced pedagogic foundations. (Dabbagh and Reo 2011). Such platforms assume a significant part in academic progression in social disciplines and pedagogical processes. Numerous researchers explained different parts of utilization of social media platforms in various training stages besides learning. Such impacts incorporate admittance to subject substance, general information, and securing of basic reasoning, moral turn of events, city support abilities and mental development (Pascarella and Terenzini 2005).

Corporations with same age over social media platforms offer a chance to learn more information from other students about actual life alongside the college (Yu et al. 2010). Contribution on social media and age to age engagement effects students and they are expected to have a good feeling of welfare, well-being, expressive progress, combined learning, confidence advance, college gratification, and academic achievement (Steineld et al. 2008; Ainin et al. 2015).

Assessment outcomes for the utilization social media depends on its boundaries, for example, quantity of times suggested for operating social networks, progress levels of web-based networks correspondences, ubiquity of informal community amongst students, also, the connection between utilization of social media and social relations with academic performance (Alwagait et al. 2015)

Kaveri Subrahmanyam besides Patricia Greenfield state that using electronic communication medium has both pros and cons effects, as there are negative methods in which the social media could be used. They believe that today, institutes are working to regulate how students use social media in schools and universities (Subrahmanyam and Greenfield, 2008). However, some school directors and managers believe that social media has influences on the progress of the students' teaching. In other schools, managers have banned the admission of social networks because of anxiety the undergraduates' communication on them, even they know the positive influences of social networks on student's knowledge (Ahn, 2010). Ahn says students used different social networks for different purposes such as they use YouTube for sharing and streaming videos, they use Facebook, to have a comprehensive online identity and make friendships. (Ahn, 2010).

\subsection{Methods and Data collection}

An online survey was conducted to collect data among university students from two public universities: university of Raparin and Sulaimani Polytechnic University in Iraqi Kurdistan Region. The survey began from $1^{\text {st }}$ December 2020 to and last January 2021, which a total 653 responses we collected. Also, Self-reporting of the high size of 
the study population would be sufficient for obtaining (Wright et al. 1998). This research relied on a content analysis method for data analysis. Consistently, the study data were analyzed by using SPSS software.

\section{Statistical Methods}

\section{Reliability of Questionnaire}

Reliability implies the testing instrument's precision, reliability, stability, and continuity. The suggested acceptable sample size is 'about 200 individuals (or more) for a survey,' according to Plano and Creswell (2018), which means that a sample size of 200 respondents is appropriate for the current research sample size.

\section{Table (1): Reliability}

\begin{tabular}{|l|c|c|}
\hline \multicolumn{1}{|c|}{ Variables } & N. of class & Alpha Cronbach's \\
\hline Use of social media & 11 & $\mathbf{0 . 8 1 4}$ \\
\hline academic skills & 11 & $\mathbf{0 . 7 8 8}$ \\
\hline Social media's impact on academic skills & 22 & 0.89 \\
\hline
\end{tabular}

\section{Resolution tests:}

Table (1) indicates that alpha Cronbach was used to derive the reliability of the participants. On the other hand, the Alpha Cronbach coefficient was used to ensure the scale's stability to determine the efficiency of the research sample members' answers. Depending on the results, the value of Alpha Cronbach coefficient is equal to (0.89) at total level of the two variables (Social media's impact on academic skills). Therefore, the alpha Cronbach value is equal to (0.89), so the alpha Cronbach result indicates the questionnaire's high reliability.

\section{The first section: Demographic variables}

Table (2): Data from demographics

\begin{tabular}{|c|c|c|c|}
\hline Variables & Items & Frequency & $\%$ \\
\hline \multirow{3}{*}{ Gender } & Male & 238 & 36.4 \\
\hline & Female & 404 & 61.9 \\
\hline & I don't like to say & 11 & 1.7 \\
\hline \multirow{3}{*}{ Age } & Less than 20 & 259 & 39.66 \\
\hline & $20-25$ years old & 339 & 51.92 \\
\hline & More than 25 & 55 & 8.42 \\
\hline \multicolumn{2}{|c|}{ Mean \pm S. D } & \multicolumn{2}{|c|}{$21.19 \pm 4.46$} \\
\hline \multirow{5}{*}{ departments at the university } & English & 141 & 21.6 \\
\hline & Nursing & 126 & 19.3 \\
\hline & Administration & 79 & 12.1 \\
\hline & Kurdish & 44 & 6.7 \\
\hline & chemistry & 42 & 6.4 \\
\hline
\end{tabular}




\begin{tabular}{|c|c|c|c|}
\hline \multirow{4}{*}{} & Law & 12 & 1.8 \\
\cline { 2 - 4 } & Biology & 5 & .8 \\
\cline { 2 - 4 } & Arabic & 57 & 8.7 \\
\cline { 2 - 4 } & Magmatic & 5 & .8 \\
\cline { 2 - 4 } & History & 16 & 2.5 \\
\cline { 2 - 4 } & Geography & 37 & 5.7 \\
\cline { 2 - 4 } & engineering & 74 & 11.3 \\
\cline { 2 - 4 } & Computer & 15 & 2.3 \\
\hline \multirow{4}{*}{ study Stage } & 1st stage & 352 & 53.9 \\
\cline { 2 - 4 } & 2nd stage & 103 & 15.8 \\
\cline { 2 - 4 } & 3rd stage & 122 & 18.7 \\
\cline { 2 - 4 } & 4th stage & 76 & 11.6 \\
\hline \multirow{2}{*}{ Total } & & $\mathbf{6 5 3}$ & $\mathbf{1 0 0 . 0}$ \\
\hline
\end{tabular}

Table (2) indicates that most respondents were female which is 61.9 percent of the outcome. This assumes the rate of females to be greater than males. The male percentage was 36.4 percent. Furthermore, $51.92 \%$ of the age was between (20-25 years of age), which was the highest rate of all other age groups, and 39.66\% was (20-25 years old), and the lowest rate of age was More than 25, which was to equal $8.42 \%$. Of the participants, $21.6 \%$ was studying in the English department, which was the highest rate. While $19.3 \%$ and $12.1 \%$ study in the (Nursing and Administration) department by, respectively. The most necessary rate of the study Stage was $1^{\text {st }}$ stage, which was $53.9 \%$ and $18.7 \%$ and $15.8 \%$ were (3rd and 2 nd stages) by respectively, and only $11.6 \%$ was $4^{\text {th }}$ stage.

The second section: Main Study variables

Table (3): descriptive some questions

\begin{tabular}{|c|c|c|}
\hline Questions & Frequency & $\%$ \\
\hline \multicolumn{3}{|c|}{ Which social media platform do you use mostly } \\
\hline (Facebook) & 475 & 24.37 \\
\hline (Twitter) & 24 & 1.23 \\
\hline (YouTube) & 259 & 13.29 \\
\hline (LinkedIn) & 11 & 0.56 \\
\hline (Viber) & 146 & 7.49 \\
\hline (Skype) & 1 & 0.05 \\
\hline (Slide share) & 11 & 0.56 \\
\hline (Google Classroom) & 206 & 10.57 \\
\hline (Instagram) & 291 & 14.93 \\
\hline (Snapchat) & 346 & 17.75 \\
\hline (WhatsApp) & 51 & 2.62 \\
\hline (Telegram) & 128 & 6.57 \\
\hline Total & 1949 & 100 \\
\hline \multicolumn{3}{|c|}{ In a day ( 24 hours) how often do you use social media? } \\
\hline Less than one count & 44 & 6.74 \\
\hline 1 to 2 hours & 179 & 27.41 \\
\hline 2 to 4 hours & 273 & 41.81 \\
\hline
\end{tabular}




\begin{tabular}{|c|c|c|}
\hline 4 to 6 hours & 138 & 21.13 \\
\hline More than 6 hours & 19 & 2.91 \\
\hline Total & 653 & 100 \\
\hline \multicolumn{3}{|c|}{ How many hours a day do you study } \\
\hline Less than one count & 74 & 11.33 \\
\hline 1 to 2 hours & 165 & 25.27 \\
\hline 2 to 4 hours & 225 & 34.46 \\
\hline 4 to 6 hours & 133 & 20.37 \\
\hline More than 6 hours & 56 & 8.58 \\
\hline Total & 653 & 100 \\
\hline \multicolumn{3}{|c|}{ What device do you use to enter social media platforms } \\
\hline Laptop (Computer) & 6 & 0.92 \\
\hline Mobile phone & 608 & 93.11 \\
\hline Table and iPad & 1 & 0.15 \\
\hline All of them & 38 & 5.82 \\
\hline Total & 653 & 100 \\
\hline \multicolumn{3}{|c|}{ For what purpose do you use social media platforms? } \\
\hline chatting in general & 167 & 25.57 \\
\hline chat with my classmates & 68 & 10.41 \\
\hline Find New Friend & 6 & 0.92 \\
\hline Obtain information & 199 & 30.47 \\
\hline Contacting my teachers & 8 & 1.23 \\
\hline Exchange information with my friends & 92 & 14.09 \\
\hline Entertainment & 113 & 17.30 \\
\hline Total & 653 & 100 \\
\hline \multicolumn{3}{|c|}{ In what way do you use social media platforms } \\
\hline Create a personal Account & 600 & 91.88 \\
\hline Create a Page & 15 & 2.30 \\
\hline Create a Group & 38 & 5.82 \\
\hline Total & 653 & 100 \\
\hline \multicolumn{3}{|c|}{ Choose the best social media platform that has an impact on the learning and academic process } \\
\hline Facebook & 153 & 10.76 \\
\hline YouTube & 703 & 49.44 \\
\hline Google classroom & 228 & 16.03 \\
\hline Google & 334 & 23.49 \\
\hline Google and zoom in & 4 & 0.28 \\
\hline Total & 1422 & 100.0 \\
\hline
\end{tabular}

It is clear from the table (3) that the majority of the using social media was (Facebook) which was $24.37 \%$ of the total while $17.75 \%$ and $14.93 \%$ were used (Snapchat) and (Instagram) by respectively, and only $1.23 \%$ was used (Twitter). In other words, $41.81 \%$ of the social media use was between ( 2 to 4 hours) in a day, and only $2.91 \%$ was used for More than 6 hours. Nevertheless, for Most participants, the highest studying rate was between ( 2 to 
4 hours). Then, $25.27 \%$ and $20.37 \%$ were between ( 1 to 2 hours) and ( 4 to 6 hours). However, the majority of the device to use social media was by Mobile phone, which was the highest rate among all devices $30.47 \%$ of the respondents use social media to gain information, and $25.57 \%$ purpose of using social media was chatting in general. $91.88 \%$ use social media platforms to Create a personal account, and $5.82 \%$ to Create a Group. Also, participants were used different platforms for learning and academic process. $49.44 \%$ of them used YouTube, and $23.49 \%$ were used Google.

Table (4): Description of variables

\begin{tabular}{|c|c|c|}
\hline $\mathrm{N}$ & variables & Questions \\
\hline 1 & $\mathrm{X} 1$ & When I spend time on social media, I am away from studying \\
\hline 2 & $\mathrm{X} 2$ & As a student using social has had effect on growth of my academic skills \\
\hline 3 & $\mathrm{X} 3$ & The hours I spent on social media are more than the hours I spent on study \\
\hline 4 & $\mathrm{X} 4$ & Through social platforms, I will follow the latest developments in my field \\
\hline 5 & $\mathrm{X} 5$ & Social networks have had adverse impact on my writing skills \\
\hline 6 & X6 & Participating in academic forums on social media make me confused \\
\hline 7 & $\mathrm{X} 7$ & Social media has affected my grades negatively \\
\hline 8 & $\mathrm{X} 8$ & $\begin{array}{l}\text { Teachers as part of the academic activities are imparting students to use social media for } \\
\text { studying purposes }\end{array}$ \\
\hline 9 & X9 & We have social media groups for our students \\
\hline 10 & $\mathrm{X} 10$ & Social media has improved my communication skills \\
\hline 11 & $\mathrm{X} 11$ & Through social media, I contact my teachers \\
\hline 12 & Y1 & My access to Facebook by mobile has negative impact on my academic skills \\
\hline 13 & Y2 & I am using social media platforms for academic discussions \\
\hline 14 & Y3 & To exchange details with my classmates, I use social media to \\
\hline 15 & Y4 & Social networking has had a beneficial influence on my grades, \\
\hline 16 & Y5 & $\begin{array}{l}\text { I just rely on the information I gain from social media platforms to carry out my study duties } \\
\text { without using other sources. }\end{array}$ \\
\hline 17 & Y6 & Using social media for research has helped me to increase my grades \\
\hline 18 & Y7 & Sometimes I use social media to understand what I have taught in class \\
\hline 19 & Y8 & I will not be good in my academic works even if I stop using social media \\
\hline 20 & Y9 & $\begin{array}{l}\text { For social relationship purposes, I use social media rather than for studying and academic } \\
\text { purposes. }\end{array}$ \\
\hline 21 & Y10 & I need to use social media a lot, because most of my tasks and projects for classes are online \\
\hline 22 & Y11 & Sometimes, when I use social media, I study too, and that makes me lost my focus \\
\hline
\end{tabular}


Table (5): Description of variables (Use of social media)

\begin{tabular}{|c|c|c|c|c|c|c|c|c|c|c|}
\hline \multirow{3}{*}{ Questions } & $\begin{array}{l}\text { Strongly } \\
\text { disagree }\end{array}$ & Disagree & $\begin{array}{c}\begin{array}{c}\text { I don't } \\
\text { know }\end{array} \\
\end{array}$ & Agree & $\begin{array}{c}\text { strongly } \\
\text { Agree } \\
\end{array}$ & \multirow{3}{*}{ Mean } & \multirow{3}{*}{ S.D } & \multirow{3}{*}{ C.V } & \multirow{3}{*}{ RI } & \multirow{3}{*}{ Rank } \\
\hline & NO & NO & NO & NO & NO & & & & & \\
\hline & $\%$ & $\%$ & $\%$ & $\%$ & $\%$ & & & & & \\
\hline \multirow{2}{*}{$\mathrm{X}_{1}$} & 91 & 142 & 178 & 189 & 53 & \multirow{2}{*}{2.97} & \multirow{2}{*}{1.18} & \multirow{2}{*}{39.73} & \multirow{2}{*}{59.4} & \multirow{2}{*}{7} \\
\hline & 13.9 & 21.7 & 27.3 & 28.9 & 8.1 & & & & & \\
\hline \multirow{2}{*}{$\mathrm{X}_{2}$} & 80 & 139 & 138 & 232 & 64 & \multirow{2}{*}{3.09} & \multirow{2}{*}{1.2} & \multirow{2}{*}{38.83} & \multirow{2}{*}{61.8} & \multirow{2}{*}{6} \\
\hline & 12.3 & 21.3 & 21.1 & 35.5 & 9.8 & & & & & \\
\hline \multirow{2}{*}{$X_{3}$} & 142 & 196 & 127 & 117 & 71 & \multirow{2}{*}{2.66} & \multirow{2}{*}{2.29} & \multirow{2}{*}{86.09} & \multirow{2}{*}{53.2} & \multirow{2}{*}{8} \\
\hline & 21.7 & 30 & 19.4 & 17.9 & 10.9 & & & & & \\
\hline \multirow{2}{*}{$\mathrm{X}_{4}$} & 58 & 109 & 226 & 209 & 51 & \multirow{2}{*}{3.13} & \multirow{2}{*}{1.07} & \multirow{2}{*}{34.19} & \multirow{2}{*}{62.6} & \multirow{2}{*}{4} \\
\hline & 8.9 & 16.7 & 34.6 & 32 & 7.8 & & & & & \\
\hline $\mathrm{Y}_{-}$ & 139 & 188 & 197 & 99 & 30 & 253 & 112 & 4427 & 506 & 10 \\
\hline$\lambda_{5}$ & 21.3 & 28.8 & 30.2 & 15.2 & 4.6 & L.J & 1.12 & 44.21 & 0.0 & 10 \\
\hline $\mathrm{Y}$ & 123 & 185 & 264 & 50 & 31 & 25 & 102 & 4104 & $50 ?$ & 11 \\
\hline$\lambda_{6}$ & 18.8 & 28.3 & 40.4 & 7.7 & 4.7 & 2.01 & 1.03 & 41.04 & 30.2 & 11 \\
\hline $\mathrm{Y}$ & 111 & 205 & 189 & 119 & 29 & 80 & 11 & 1100 & 52, & , \\
\hline$X_{7}$ & 17 & 31.4 & 28.9 & 18.2 & 4.4 & 2.02 & 1.1 & 41.98 & 32.4 & 9 \\
\hline $\mathrm{X}_{\mathrm{H}}$ & 69 & 105 & 193 & 203 & 83 & 310 & 117 & 3668 & 638 & 2 \\
\hline$X_{8}$ & 10.6 & 16.1 & 29.6 & 31.1 & 12.7 & 3.19 & 1.11 & 30.68 & 03.8 & 2 \\
\hline $\mathrm{X}_{\mathrm{N}}$ & 60 & 92 & 148 & 230 & 123 & 34 & 121 & 3550 & 68 & 1 \\
\hline$X_{9}$ & 9.2 & 14.1 & 22.7 & 35.2 & 18.8 & 3.4 & 1.21 & 35.59 & 68 & 1 \\
\hline $\mathrm{Y}$ & 76 & 104 & 197 & 215 & 61 & 27 & 115 & 2606 & 62 & 5 \\
\hline$X_{10}$ & 11.6 & 15.9 & 30.2 & 32.9 & 9.3 & 3.12 & 1.15 & 30.80 & 02.4 & 5 \\
\hline$X_{1}$ & 86 & 91 & 198 & 192 & 86 & 315 & 121 & 3841 & 63 & 3 \\
\hline$\lambda_{11}$ & 13.2 & 13.9 & 30.3 & 29.4 & 13.2 & $0.1 J$ & 1.21 & 50.41 & oJ & $J$ \\
\hline Sum & 1035 & 1556 & 2055 & 1855 & 682 & 204 & 125 & 4306 & 5885 & \\
\hline Sumi & 14.41 & 21.66 & 28.61 & 25.82 & 9.49 & 2.94 & 1.20 & 43.00 & 50.0כ & \\
\hline
\end{tabular}

*RI : relative importance, $\mathrm{C} . \mathrm{V}$ : coefficient of variance

The repeat distribution data in Table (5) (mean, stander deviation, coefficient of variance, and relative significance) indicate explanatory variables that concentrate on (Use of social media). This variable has a mean of (2.94). And a standard deviation of (1.25) and the relative significance of (1.25) (58.85 percent). The rate of someone who replied with "strongly agree" (9.49 percent), who (agreed) by (25.82 percent), who was do not know was (28.61 percent), whereas the percentage of someone who disagree and strongly disagree the rate was (36.07 percent). 
Table (6): Description of variables (Academic Skills)

\begin{tabular}{|c|c|c|c|c|c|c|c|c|c|c|}
\hline \multirow{3}{*}{ Questions } & $\begin{array}{l}\text { Strongly } \\
\text { disagree }\end{array}$ & Disagree & $\begin{array}{l}\text { I don't } \\
\text { know }\end{array}$ & Agree & $\begin{array}{c}\text { strongly } \\
\text { Agree }\end{array}$ & \multirow{3}{*}{ Mean } & \multirow{3}{*}{ S.D } & \multirow{3}{*}{ C.V } & \multirow{3}{*}{ RI } & \multirow{3}{*}{ Rank } \\
\hline & NO & NO & NO & NO & NO & & & & & \\
\hline & $\%$ & $\%$ & $\%$ & $\%$ & $\%$ & & & & & \\
\hline \multirow{2}{*}{$\mathrm{X}_{1}$} & 133 & 216 & 199 & 84 & 21 & \multirow{2}{*}{2.45} & \multirow{2}{*}{1.05} & \multirow{2}{*}{42.86} & \multirow{2}{*}{49} & \multirow{2}{*}{9} \\
\hline & 20.4 & 33.1 & 30.5 & 12.9 & 3.2 & & & & & \\
\hline \multirow{2}{*}{$\mathrm{X}_{2}$} & 61 & 116 & 257 & 184 & 35 & \multirow{2}{*}{3.02} & \multirow{2}{*}{1.02} & \multirow{2}{*}{33.77} & \multirow{2}{*}{60.4} & \multirow{2}{*}{4} \\
\hline & 9.3 & 17.8 & 39.4 & 28.2 & $\overline{5.4}$ & & & & & \\
\hline \multirow{2}{*}{$\mathrm{X}_{3}$} & 51 & 95 & 156 & 250 & 101 & \multirow{2}{*}{3.39} & \multirow{2}{*}{1.14} & \multirow{2}{*}{33.63} & \multirow{2}{*}{67.8} & \multirow{2}{*}{1} \\
\hline & 7.8 & 14.5 & 23.9 & 38.3 & 15.5 & & & & & \\
\hline \multirow{2}{*}{$\mathrm{X}_{4}$} & 83 & 153 & 219 & 149 & 49 & \multirow{2}{*}{2.89} & \multirow{2}{*}{1.12} & \multirow{2}{*}{38.75} & \multirow{2}{*}{57.8} & \multirow{2}{*}{7} \\
\hline & 12.7 & 23.4 & 33.5 & 22.8 & 7.5 & & & & & \\
\hline & 168 & 231 & 178 & 55 & 21 & & & & 156 & 11 \\
\hline $\mathrm{X}_{5}$ & 25.7 & 35.4 & 27.3 & 8.4 & 3.3 & 2.28 & 1.04 & 43.61 & 43.6 & 11 \\
\hline $\mathrm{Y}$ & 54 & 125 & 166 & 237 & 71 & 320 & 113 & 3500 & 644 & 3 \\
\hline$X_{6}$ & 8.3 & 19.1 & 25.4 & 36.3 & 10.9 & 3.22 & 1.13 & 35.09 & 64.4 & 3 \\
\hline $\mathrm{X}_{7}$ & 54 & 90 & 185 & 243 & 81 & 332 & 111 & 3343 & 664 & 2 \\
\hline$X_{7}$ & 8.3 & 13.8 & 28.3 & 37.2 & 12.4 & 3.32 & 1.11 & 33.43 & 66.4 & 2 \\
\hline $\mathrm{Y}$ & 136 & 196 & 228 & 69 & 24 & P & 105 & 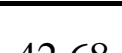 & & 0 \\
\hline $\mathrm{X}_{8}$ & 20.8 & 30 & 34.9 & 10.6 & 3.7 & 2.46 & 1.05 & 42.68 & 49.2 & 8 \\
\hline & 173 & 184 & 202 & 70 & 24 & 237 & 11 & & & 10 \\
\hline $\mathrm{X}_{9}$ & 26.5 & 28.2 & 30.9 & 10.7 & 3.7 & 2.37 & 1.1 & 46.41 & 47.4 & 10 \\
\hline $\mathrm{Y}$ & 72 & 143 & 206 & 172 & 60 & & & & & \\
\hline $\mathrm{X}_{10}$ & 11 & 21.9 & 31.5 & 26.3 & 9.2 & 3.01 & 1.14 & 37.87 & 60.2 & 5 \\
\hline & 102 & 154 & 154 & 163 & 80 & & & & & \\
\hline $\mathrm{X}_{11}$ & 15.6 & 23.6 & 23.6 & 25 & 12.3 & 2.95 & 1.26 & 42.71 & 59 & 6 \\
\hline & 1087 & 1703 & 2150 & 1676 & 567 & & & 3035 & 5700 & \\
\hline Sum & 15.13 & 23.71 & 29.93 & 23.33 & 7.89 & 2.85 & 1.11 & 39.35 & 57.02 & \\
\hline
\end{tabular}

The repeat distribution data in Table (6) (mean, stander deviation, coefficient of variance, and relative significance) indicate explanatory variables that concentrate on (Academic Skills). This variable has an average value of (2.85). And a standard deviation of (1.11) and the relative significance of (57.02 percent). The percentage of people who replied with "strongly agree" (7.89 percent), who were (agree) (23.33 percent), who were somewhat (do not know) (29.93 percent), while the percentage of people who did not agree and strongly disagree with the paragraphs surpassed the rate was (38.84 percent). 
Table (7): The association between social media usage and academic skills

\begin{tabular}{|c|c|c|c|}
\hline \multirow{2}{*}{ Variables } & \multicolumn{3}{|c|}{ Use of social media } \\
\cline { 2 - 4 } & Correlation & Sig. & Sample \\
\hline Academic skills & $\mathbf{0 . 8 0 9}$ & $\mathbf{0 . 0 0 0}$ & $\mathbf{6 5 3}$ \\
\hline \multirow{3}{*}{$*$ The level of significance at level 0.05} \\
*There is association among the statistical function between social media and academic skills
\end{tabular}

Ho: There is no correlation among Use of social media and academic skills

H1: There is correlation among Use of social media and academic skills.

Table (7) shows that there is a statistically significant correlation between Use of social media and academic skills, which is $(0.809)$ and that the significance value is $(0.000)$ this means accepting the second hypothesis because the $\mathrm{p}$-value was less than (0.05). And also, there is a strong positive correlation between Use of social media and academic skills.

Table (8): Regression analysis of a dependent variable (academic skills)

The use of social media and its effect on university students' academic skills in the Iraqi Kurdistan

Region

\begin{tabular}{|c|c|c|c|c|c|c|c|c|c|}
\hline \multirow{3}{*}{ Model } & \multicolumn{4}{|c|}{ Coefficients } & \multicolumn{3}{|c|}{ Model Summary } & \multicolumn{2}{|c|}{ ANOVA Table } \\
\hline & \multicolumn{2}{|c|}{$\begin{array}{r}\text { Unstandardized } \\
\text { Coefficients }\end{array}$} & \multirow[t]{2}{*}{ T Test } & \multirow[t]{2}{*}{ Sig. } & \multirow[t]{2}{*}{$\mathbf{R}$} & \multirow[t]{2}{*}{$\mathbf{R}^{2}$} & \multirow{2}{*}{$\underset{2}{\operatorname{Adj} .(R}$} & \multirow[t]{2}{*}{ F Test } & \multirow[t]{2}{*}{ Sig. } \\
\hline & $\mathbf{B}$ & \begin{tabular}{|l|} 
Std.Error \\
\end{tabular} & & & & & & & \\
\hline Constant & 0.671 & $\begin{array}{r}0.064 \\
\end{array}$ & 10.53 & 0.000 & 0800 & 0.655 & 0654 & 1223550 & 0000 > \\
\hline Use of social media & 0.741 & 0.021 & 35.12 & 0.000 & & & & & \\
\hline
\end{tabular}

Ho: social media and its effect on academic skills do not exist.

H1: social media and its effect on academic skills are present.

This table illustrates that the model of regression substantially predicts the dependent variable well. This demonstrates the statistical importance of the type of regression used. The (p-value) was $(0.000)$, which is less than 0.05 , which shows that the regression model predicts the outcome variable statistically significantly (it is a good fit for the data). This implies that this data can be evaluated by the methodology, suggesting approval of the alternative hypothesis.

The value of $\mathrm{R}$ is to equals (0.809) meaning that there is a strong positive correlation between Use of social media and academic skills. In other words, $\mathrm{R}$ Square for this analysis is (0.655). This means that $65.5 \%$ of the variance of academic skills must be explored in Use of social media, this illustrates that only $65.5 \%$ of factors affect academic skills in (Use of social media and the other variables (34.5\%) are due to random error. 


\section{Conclusion:}

Social network platforms are electronic apparatuses that are useful for improving instruction in colleges and advanced pedagogical foundations. Corporations of the same age provide an opportunity to learn more knowledge from other students about real life alongside the college through internet media platforms. Undergraduates are required to have a good feeling of welfare, well-being, expressive development, combined learning, trust growth, college gratification, and academic achievement through contributing to digital media and age to age engagement impact.

The findings of this research demonstrate how the independent variable can overcome much of the overall variance in the dependent variable. The ratio is, 65.5 percent, which is very high, can be explained. Just $61.1 \%$ of variables have an impact on (academic skills)

\section{Strengths of the Study}

This is the first research evaluating the impact of social media platforms on undergraduates' academic skills in Iraqi Kurdistan Region universities: and one of the few studies conducted in the Middle Eastern courtiers. 


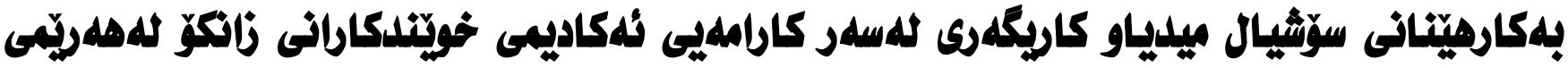 كوردستان - ميّراق}

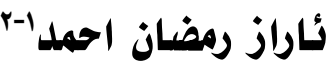

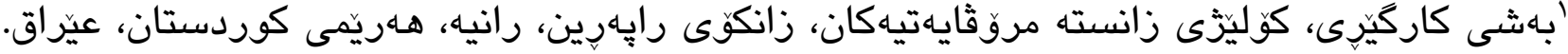

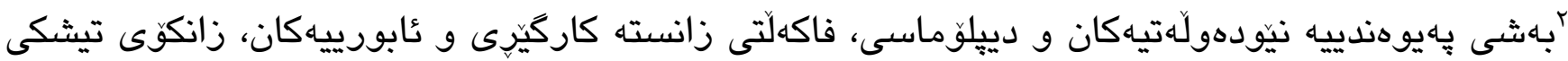

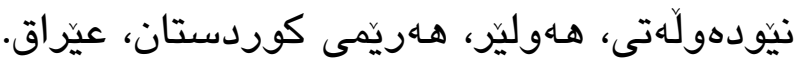
araz.ahmad85@uor.edu.krd :ئيميل

\section{حلكيم عثمان حميد}

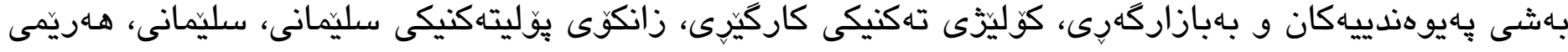

$$
\text { كوردستان، عيّراق. }
$$

hakim.othman@spu.ede.iq ئيمهيل:

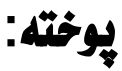

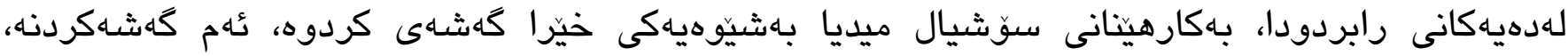

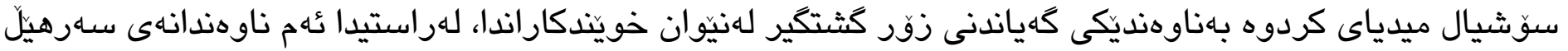

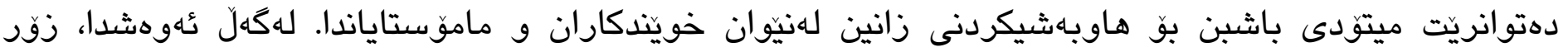

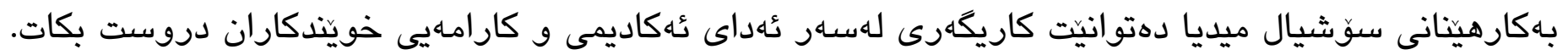

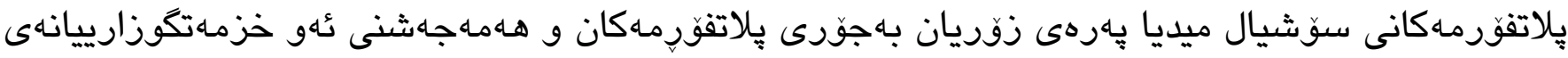

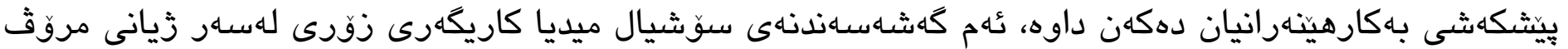

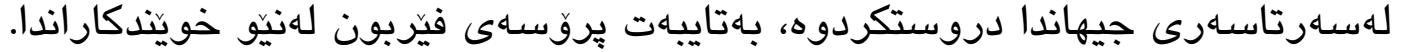




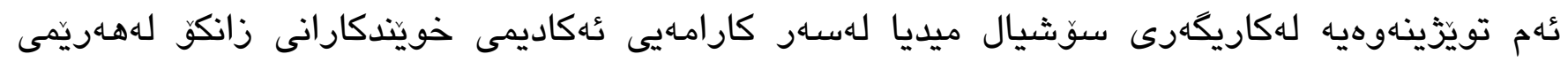

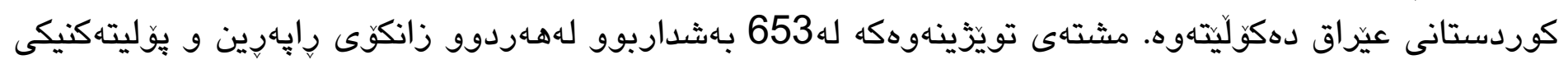

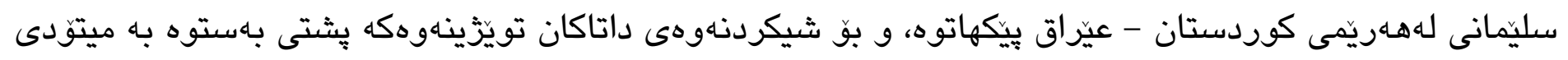
شيكارى ناوهروّك.

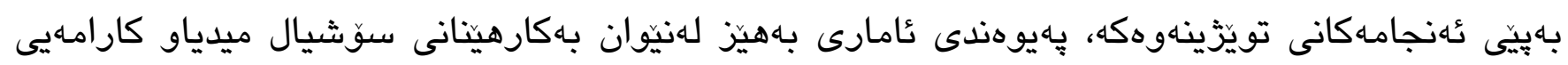

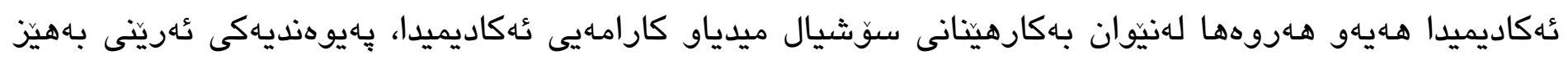

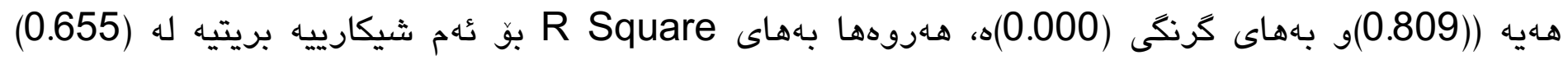

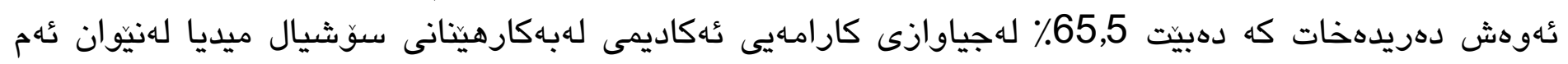

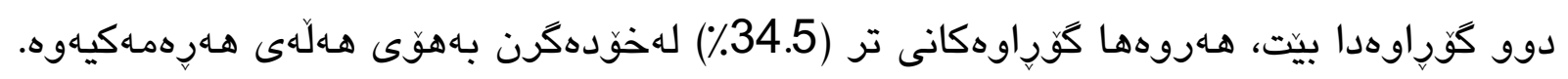

كاله وشُكان: كاريكهرى، سوّشيال ميديا، كارامهيى عُهاديمى، عيّراق، هـريّى كوردستان. 


\section{References:}

Ahmad, A.R. and Murad, H.R., 2020. The impact of social media on panic during the COVID-19 pandemic in Iraqi Kurdistan: online questionnaire study. Journal of medical Internet research, 22(5), p.e19556.

Ahmad, A.R. and Hamasaeed, N.H.H.H., 2015. The Role of Social Media in the 'Syrian Uprising'. Journal of Economic Development, Environment and People, 4(2), pp.39-48.

Adams, B., Raes, A., Montrieux, H., \& Schellens, T. (2018). "Pedagogical tweeting” in higher education: Boon or bane? International Journal of Educational Technology in Higher Education, 15(1), 19. https://doi.org/10.1186/s41239-018-0102-5

Ahn, J. (2010). The Influence Of Social Networking Sites on High School Students' Social and Academic Development. Diss. Faculty of the USC Graduate School University of Southern California.

Ainin, S., Parveen, F., Moghavvemi, S., Jaafar, N. I., \& Mohd Shuib, N. L. (2015a). Factors influencing the use of social media by SMEs and its performance outcomes. Industrial Management \& Data Systems, 115(3), 570-588. https://doi.org/10.1108/IMDS-07-2014-0205.

Ainin, Sulaiman; Naqshbandi, M. Muzamil; Moghavvemi, Sedigheh and Ismawati Jaafar, Noor (2015b). Facebook usage, socialization and academic performance. Computers \& Education 83, 64-73. https://doi. org/10.1016/j.compedu.2014.12.018.

Alizadeh, I. (2018). Evaluating the educational usability of telegram as an SNS in ESAP programs from medical students' perspective. Education and Information Technologies, 23(6), 2569-2585. https://doi.org/10.1007/s10639-018-9731-5.

Al-Khalifa, H. S., \& Garcia, R. A. (2013). "The state of social media in Saudi Arabia higher education." International Journal of Technology and Educational Marketing (IJTEM), 3, 65-76.

Al-Rahmi, W., Othman, M. S., \& Musa, M. A. (2014). The improvement of students' academic performance by using social media through collaborative learning in Malaysian higher education. Asian Social Science, 10(8), 210-221. https://doi.org/10.5539/ass.v10n8p210

Alwagait, E., Shahzad, B., \& Alim, S. (2015). Impact of social media usage on students' academic performance in Saudi Arabia. Computers in Human Behavior, 51, 1092-1097. https://doi.org/10.1016/j.chb.2014.09.028.

Arafat, S.M., Ahmad, A.R., Murad, H.R. and Kakashekh, H.M., 2021. Perceived Impact of Social Media on Panic Buying: An Online Cross-Sectional Survey in Iraqi Kurdistan. Frontiers in Public Health, 9, p.447.

Beeland Jr, W. D. (2002). Student engagement, visual learning and technology: can interactive whiteboards help?. 
Brislin, R. W. (1970). Back-translation for cross-cultural research. Journal of Cross-Cultural Psychology, 1, 185216. https://doi.org/10.1177/135910457000100301

Camilia, N. C., Ibrahim, S. D., \& Dalthu, B. L. (2013). "The effect of social networking sites usage on the studies of Nigerian students." The international Journal of Engineering And Science, 2, $39-46$.

Chugh, R., \& Ruhi, U. (2018). Social media in higher education: A literature review of Facebook. Education and Information Technologies, 23(2), 605-616. https://doi.org/10.1007/s10639-017-9621-2.

Conner, T. (2011). Academic engagement ratings and instructional preferences: Comparing behavioral, cognitive, and emotional engagement among three school-age student cohort. Review of Higher Education \& Self-Learning, 4(13).

Courtner, A. S. (2014). Impact of student engagement on academic performance and quality of relationships of traditional and nontraditional students. International Journal of Education, 6(2), 24-45

Creswell JW , Plano Clark VL (2018) Designing and conducting mixed methods research. 3rd edn. Sage Publications.

Dabbagh, N., \& Reo, R. (2011). Back to the future: Tracing the roots and learning. Web 2.0-Based e-learning: Applying social informatics for tertiary Teaching: Applying social informatics for tertiary teaching, 1, 1-20. https://doi.org/10.4018/978-1-60566-294-7.ch001.

Dahlstrom, E. (2012). ECAR study of undergraduate students and information technology. Louisville: EDUCAUSE Center for Applied Research Available from http://www.educause.edu/ecar

Dahlstrom, E., de Boor, T., Grunwald, P., \& Vockley, M. (2011). ECAR national study of undergraduate students and information technology (Research study, Vol. 6). Boulder, CO: EDUCAUSE Center for Applied Research.

El-Badawy, T.A. and Hashem, Y., 2015. The impact of social media on the academic development of school students. International Journal of Business Administration, 6(1), p.46.

Huffman, W. H., \& Huffman, A. H. (2012). Beyond basic study skills: The use of technology for success in college. Computers in Human Behavior, 28(2), 583-590. https://doi.org/10.1016/j.chb.2011.11.004

Ivala, E., \& Gachago, D. (2012). Social media for enhancing student engagement: The use of Facebook and blogs at a university of technology. South African Journal of Higher Education, 26(1), 152-167

Junco, R. (2012). Too much face and not enough books: The relationship between multiple indices of Facebook use and academic performance. Computers in Human Behavior, 28(1), 187-198. https://doi.org/10.1016/j.chb.2011.08.026. 
Junco, R., Heiberger, G., \& Loken, E. (2011). The effect of twitter on college student engagement and grades. Journal of Computer Assisted Learning, 27(2), 119-132. https://doi.org/10.1111/j.13652729.2010.00387.x.

Kaplan, A. M., \& Haenlein, M. (2010). Users of the world, unite! The challenges and opportunities of social media. Business Horizons, 53(1), 59-68. https://doi.org/10.1016/j.bushor.2009.09.003.

Kietzmann, J. H., Hermkens, K., McCarthy, I. P., \& Silvestre, B. S. (2011). Social media? Get serious! Understanding the functional building blocks of social media. Business horizons, 54(3), 241251.https://doi.org/10.1016/j.bushor.2011.01.005.

Kolan, Bernard John and Dzandza, Patience Emefa, (2018). "Effect of Social Media on Academic Performance of Students in Ghanaian Universities: A Case Study of University of Ghana, Legon." Library Philosophy and Practice (e-journal). 1637. https://digitalcommons.unl.edu/libphilprac/1637

Kuh, G. D. (2009). What student affairs professionals need to know about student engagement? Journal of College Student Development, 50(6), 683-706. https://doi.org/10.1353/csd.0.0099

Kuh, G. D., Cruce, T. M., Shoup, R., Kinzie, J., \& Gonyea, R. M. (2008). Unmasking the effects of student engagement on first-year college grades and persistence. The Journal of Higher Education, 79(5), 540563. https://doi.org/10.1080/00221546.2008.11772116.

Leonardi, P. M., Huysman, M., \& Steinfield, C. (2013). Enterprise social media: Definition, history, and prospects for the study of social technologies in organizations. Journal of Computer-Mediated Communication, 19(1), 1-19. https://doi.org/10.1111/jcc4.12029.

Mahdiuon, R., Salimi, G. and Raeisy, L., 2019. Effect of social media on academic engagement and performance: Perspective of graduate students. Education and Information Technologies, pp.1-20.

Narayanasamy, F., \& Mohamed, J. (2013). Adaptation of mobile learning in higher educational institutions of Saudi Arabia. International Journal of Computer Applications, 69(6), 34-38 Retrieved from http://citeseerx.ist.psu.edu/viewdoc/download?doi=10.1.1.403.7387\&rep=rep1\&type=pdf

Oueder, M. and Abousaber, I., 2018. A Study on the Impact of Social Media Usage on Student Academic Performance: University of Tabuk an Example. American Scientific Research Journal for Engineering, Technology, and Sciences (ASRJETS), 40(1), pp.77-88.

Owusu-Acheaw, M. and Larson, A.G., 2015. Use of social media and its impact on academic performance of tertiary institution students: A study of students of Koforidua Polytechnic, Ghana. Journal of Education and Practice, 6(6), pp.94-101.

Pascarella, E. T., \& Terenzini, P. T. (2005). How college affects students (Vol. 2). San Francisco: Jossey-Bass. 
Pascarella, E. T., \& Terenzini, P. T. (2005). How college affects students (Vol. 2). San Francisco: Jossey-Bass

Pasek, J., \& Hargittai, E. (2009). Facebook and academic performance: Reconciling a media sensation with data. First Monday, 14(5). https://doi.org/10.5210/fm.v14i5.2498

Peters, A. M., Crane, D., \& Costello, J. (2019). A comparison of students' twitter use in a postsecondary course delivered on campus and online. Education and Information Technologies, 24(4), 2567-2584.

Sánchez, R. A., Cortijo, V., \& Javed, U. (2014). Students' perceptions of Facebook for academic purposes. Computers \& Education, 70, 138-149. https://doi.org/10.1016/i.compedu.2013.08.012.

Saud, M., Ida, R., Abbas, A., Ashfaq, A. and Ahmad, A.R., 2020. The social media and digitalization of political participation in youths: An Indonesian perspective. Society, 8(1), pp.83-93.

Shahbaz, M., \& Khan, R. M. I. (2017). Use of Mobile immersion in foreign language teaching to enhance target language vocabulary. MIER Journal of Educational Studies, Trends and Practices, 7(1), 66-82

Steineld, C., Ellison, N. B., \& Lampe, C. (2008). Online social network use, self-esteem, and social capital: A longitudinal analysis. Journal of Applied Developmental Psychology, 29, 434-445.

Subrahmanyam, K., \& Patricia, G. (2008). Online Communication and Adolescent Relationships. The Future of Children, 18(1), 119-46. http://dx.doi.org/10.1353/foc.0.0006

Tang, T. L. P., \& Austin, M. J. (2009). Students' perceptions of teaching technologies, application of technologies, and academic performance. Computers \& Education, 53(4), 1241-1255. https://doi. org/10.1016/j.compedu.2009.06.007

Wiley, C., \& Sisson, M. (2006). Ethics, Accuracy and Assumption: the use of Facebook by students and employers. Paper presented at the Southwestern Ohio Council for higher education Special Topics Forums, Dayton, OH. Retrieved from https://www.books.google.com.gh.

Wise, L. Z., Skues, J., \& Williams, B. (2011). Facebook in higher education promotes social but not academic engagement. Changing demands, changing directions. Proceedings ascilite Hobart, 1332-1342

Wright, D. L., Aquilino, W. S., \& Supple, A. J. (1998). A comparison of computer-assisted and paper-andpencil self-administered questionnaires in a survey on smoking, alcohol, and drug use. Public Opinion Quarterly, 62, 331-353

Yu, A. Y., Tian, S. W., Vogel, D., \& Kwok, R. C. W. (2010). Can learning be virtually boosted? An investigation of online social networking impacts. Computers \& Education, 55(4), 1494-1503. https://doi.org/10.1016/j.compedu.2010.06.015.

Yusoff, S., Yusoff, R., \& Md Noh, N. H. (2017). Blended learning approach for less proficient students. SAGE Open, 7(3), 1-8. https://doi.org/10.1177/2158244017723051 